\title{
The Comparison of Adopted-Children and Biological-Children in Inheritance According to "Mbaham" Tribe The Customary Law and Islamic Law of as Well as The Role of The Notary in The Making of Inheritance Agreement
}

\author{
Dikha San Mahresi ${ }^{1}$ and Akhmad Khisni ${ }^{2}$
}

\begin{abstract}
The legal system or the rules of "Mbaham" tribe customs in Fak-Fak town Papua and Islamic legal system headed for the adopted-children and biological children about the inheritance can be compared, because both of these rules can be different systems and can also be the same, especially in determining the rights of each child's portion. It also refers to a notary whose position has specific tasks to do the agreement of inheritance when the heirs want the services of a notary. The main problems of the research as follows; one, how the comparison of the adopted-children's and the biological children's rights in inheritance according to "Mbaham" tribe customary law and Islamic law as well as the role of the public notary in the creation of the certificate. Second, what is the equality of the rights of biological children and adopted-children in the inheritance according to the customary law of Mbahan tribe and Islamic law. Third, what is the difference of the rights of biological children and adopted children in the inheritance according to the customary law of "Mbaham" tribe and Islamic law. This research used a juridic empirical approach, with the specification research of descriptive analysis. The type and source of data which were used, namely primary and secondary data and the techniques of data gathering was the primary, secondary, and tertiary data. This research also used qualitative analysis to analyze the data. The results of this research showed that, Islamically the system was Individual, where the inheritance became the property of the class who has been defined in the provisions of Islamic law based on bilateral kinship. Being in the customs of "Mbaham" tribe was not necessarily because it could accept Islamic law as the guideline, but sometimes, it differed in accordance with custom. For the role of the public notary can be used in the manufacture of the agreement of inheritance when the heirs want to disburse the funds stored in the bank. The consequences of the law which was happened headed for the adopted-children and biological children was both still get each inheritance, but all were depended on the provisions within the follow, whether the customary law or Islamic law. The notary could give advice and help the beneficiary in the making of inheritance agreement.

Keywords: Comparison; Inheritance; Notary
\end{abstract}

\section{Introduction}

Indonesia is a country that recognizes the enforceability of customary law. Even in this modern, era the customary law is still used as a reference for measuring and protecting each indigenous rights in Indonesia. Customary law is the system of rules in Indonesia public life which comes from the customs and made hereditary, respected even adhered by the community. ${ }^{3}$

There is also the law of the religion embraced by Indonesia people with each different beliefs of their lives as a guidance as well as the moral grip on every human being, therefore the country of Indonesia made a religious law as a reference and basic

\footnotetext{
${ }^{1}$ Student of Master Program in Notary Program UNISSULA email dikhaasan22@gmail.com

2 Lecturer of Faculty of Law UNISSULA

${ }^{3}$ Sudarsono 2007 Kamus Hukum Cet V Rineka Cipta Jakarta pp.39
} 
instruction in a country, so that is not the case of misunderstanding and injustice. A Papua region in Eastern of Indonesia is one of the places where the customary law is very forced and the law is enforced because of the indigenous peoples of New Guinea uphold ancestral rule, in the local myth if it would violate the rules of the customary, the actors would get disaster and hardship in their life.

The customary law has always been a consideration headed for any cases in Indonesia. However, among the multitude of terms from the fields of law, the ones who fixed on a national inheritance law or legislation governing the issue of succession would not be parted from the provisions of the inheritance customs and also heir to Islam. ${ }^{4}$

Indonesia legal heir is still Pluralistis, as it currently applies three legal systems of inheritance, namely the law of Inheritance Law in Islamic Inheritance customs, as well as the book of the law of civil law, which still applies up to this date and always be a consideration in terms of inheritance.

In the development of laws, this term is becoming a proper thing to be examined and socialized, because the case of heir became part of the Notary authority when creating Inheritance Certificate. If the notary was requested by the concerning parties, certainly the notary must look for such problem-solving by doing the development and sort out all the rules that was applied in Indonesia to avoid unlawful conditions.

We know that the profession of public notary is a public officer who is appointed by the State to serve the community in the matters of exceptional authority of public notary, including the case of inheritance because if there is a beneficiary of the community came to Office with the goal of making a description notarized letter of the beneficiary either her original communities of Papua or not, it is still a notary as a neutral party would do what is needed by the community and find troubleshooting if there is a problem encountered by the notary of the client who came to the notary.

The notary also makes their own position as public officials state that give legal certainty to the public, because public officials is a public notary who had been appointed by the State and authorized in the manufacture of the authentic agreement, then in this case the authentic notary agreement is a legitimate agreement and credible by the State and society. ${ }^{5}$ By this statement, the society can have the assurance and confidence in the making of legal agreements and in the making of the beneficiary agreement. The client who came to the notary wanted the justice and in accordance with the conditions and guarantee legal certainty that looked for fairness can be according to the wishes of the community.

The agreements which are issued by a notary is an authentic agreement that can be trusted and have legal certainty as well as recognized by the State. However, in terms of inheritance in Papua to create the agreement of inheritance/inheritance certificate with the aim of helping the beneficiary, it would become a mandatory that the notary was not just looking at one side and a legal point of view. Because in Papua there are three sources valid law of inheritance, such as: customary law, Islamic law, and Western Law. The third source of the law became the references and guidelines for the notary in order to give legal certainty, that is appropriate and acceptable for the society in Papua, especially for the majority community is a native Papua. Therefore, the notary was entrusted in making the authentic agreement must see the causal law that would be occurred if the notary makes an Act relating to the public especially related to indigenous people. The responsibility of the notary of the agreements that have been made becoming her/his

\footnotetext{
${ }^{4}$ C.S.T Kansil christine 2011 Pengantar Hukum Indonesia Rineka Cipta Jakarta pp 40

5 Soegianto 2015 Etika Profesi dan Perlindungan Hukum bagi Notaris CV Farisma Indonesia Yogyakarta pp. 15
} 
responsibilities persistently, therefore why the notaril Act is the existing evidence of a legitimate and recognized by the State as well as the entire community. ${ }^{6}$

\section{Research Method}

The research method is an activity based on the scientific method, systematics and certain thinking, that is aiming to learn one or more symptoms of a particular law, using the analysis path. It also held in-depth examination against the law facts, to dress a best resolution of the problems arising in the relevant symptoms. ${ }^{7}$

A research method that is used in this study is an empirical juridical approach. Juridical approach, is used to analyze the regulation relating to the Islamic law of Inheritance. Then the empirical approach is used to analyze the Law, which is seen as a society's behavior patterned in public life which always interact and connect in the civic aspect is often referred to as tradition, Habit or law.

\section{Results And Discussions}

\subsection{The comparison of the rights of adopted-children and Biological Children in Inheritance according to the customary law and Islamic law of Tribe "Mbaham" as well as the role of the notary Certificate Creation against Heirs}

According to the King of the tribe of "Mbaham", i.e. King Jonathan Uswanas that included some areas and existing tribes surrounding his reign in the town of Fak-Fak when he was met in the busy time said that lot of things that can be compared in terms of that are related to the rights of adopted children and biological children in inheritance customs, even good-and-bad can be seen.

Moreover, in the tribe of "Mbaham" in the town of Fak-Fak Papua legal customary law had different systems that is applying Government system, in contrast with the other areas that are in the land of Papua (the term of New Guinea Native), which uses the system to Ondoafian/Ondofolo or usually called as the Chief/head of the village. In the town of FakFak the places of "Mbaham" Tribe has a system of Government that has since been hereditary since the ancestors and became ancestral heritage which is currently still running, therefore the excess children in the tribe of "Mbaham", moreover, he was the descendants of a King even will automatically assume the Office and continued to the King to run the Government in the sense of supervises all the tribes and indigenous peoples who were there. The responsibility must be run rightly and could not resist because it has become customary law which is applicable to hereditary from a common ancestor. The biological children have an important role when he became an heir of the deceased heir, because he had to look back at the relatives of the heir, could not simply close my eyes without taking into account the system of kinship in indigenous peoples.

Then later the adopted-children, or usually in indigenous peoples in Papua could refer to as a foster child, adopted children in which there is a wide variety of things that can underlie the occurrence of adopted-children in families.

In contrast to the legacy thing, in the legal systems of the indigenous tribe of "Mbaham" adopted-children also had the right to get the inheritance from the heir of the deceased, whether it was from a will of the heir apparent or even recognition of indigenous elders Congress together, however, typically the custom was certainly adopted-child get a piece

\footnotetext{
${ }^{6}$ Mulyoto 2012 Perjanjian edisi revisi Cakrawala Media Yogyajakarta p. 38

7 http://belajarpsikologi.com accessed 21 april 2018 at 04:00 wib
} 
of the treasure heritage because it has been regarded as a child and became a part of the family. In contrast to the biological-children, in terms of inheritance the biological-children already have a fixed place in the share of indigenous families and indigenous peoples. As well as in the inheritance the biological-children have rights which still got part of the legacy left by the heir. Even before the heir of deceased children already have their place in the inheritance as well as full recognition of indigenous peoples. Not only that the advantages of the biological-children were also recognized by the State and has recorded an important part of the family. However, children still had the bad side, that in the perspective of the indigenous tribe of "Mbaham" children could just get the smallest part in the legacy of the family even didn't get anything that he would receive. This could happen when the biological-children during his lifetime never stay with the heir or go somewhere, then other things that became the biological-children only get a part of the inheritance because of the testament or the granting of the heir to the adopted child, this could happen because of the willingness of the appropriate heir could just lift up the adoptedchildren during his lifetime that maintain and take care of him until he died.

In the event of the beneficiary agreement to the native Isbandi according to Idris, Sh. Mkn a notary in Jayapura staff who have long worked in the Notary Office say that, regarding the inheritance certificate, actually could be made under the hand or could be created by the beneficiary itself and is submitted to the bank, but in practice in the bank, sometimes the bank requested that the inheritance certificate to be made a notary agreement certificate or a notary agreement that had been signed or approved by the notary. ${ }^{8}$

Generally in the Islamic law or Sharia the rights of adopted-children and biological children in inheritance has been set out in the Koran, because the Qur'an as a guidance of the muslim/Islamic people, that provision had been there and could not be replaced by the terms of any kind. In Act No. 01 Year 1974 about marriage, article 42 says "a legitimate child or children are children who were born in or as a result of a valid marriage", then in the compilation of Islamic law (GENGHIS) Article 99, legitimate child or children 1) a child who was born in or due to legitimate marriage and 2) results from the fertilization of the husband and wife are valid outside the womb and be born by the wife.

The most fatal to the biological-children when there was a recognition of the indigenous peoples or indigenous elders who claimed that the adopted child has full rights of inheritance against the heir apparent, the reasons that occurred could have been anything that fits the provisions of the customs, as customary law always applies in the indigenous tribe of "Mbaham". Other decisions could be taken in the customary law of the tribe of "Mbaham" by decision of the King of the tribe of "Mbaham" as the top brass of the tribes that are below him, but it can happen if there is a family and there is no dispute settlement although already spoken in the Indigenous Congress. ${ }^{9}$

\subsection{The equality of adopted-children and biological children in inheritance according to tribal customary law of "Mbaham" and Islamic law}

According to "Mbaham", adopted children and biological-children alike had the right getting the inheritance. Because from the standpoint of customary law, children of both foster children had both lived and lived by the heir, into a single unity of the relatives in the family. From the opinion of the King of the tribe of "Mbaham" Jonathan Uswanas said, why the rights of adopted children and biological children being born due to adopted children and biological children of indigenous children who had become protected by the custom,

\footnotetext{
${ }^{8}$ An interviewed with Isbandi Idris Staf Notaris Kota Jayapura on 25 june 2018 at 22:00

${ }^{9}$ An interviewd with Raja Suku Mbaham Thata Muchtar Uswanas 31 May 2018 at 21:00
} 
then from the custom view, also adopted child and a child bladder being right because it has been deemed to have an emotional closeness because brothers in the family, the recognition of the biological-children against adopted children who think he is his brother, although not blood connected, has become a benchmark that their rights are the same in the inheritance customs, and have become children of the indigenous customary law systems in the tribe of "Mbaham". In the indigenous tribe of "Mbaham" adopted children who have long and enter into a family then he is entitled to wear a clan from the family because of its rights in the family ever be the same.

\subsection{The difference right of adopted children and biological children in inheritance according to tribal customary law of "Mbaham" and Islamic law}

The biological children have significant differences from adopted-children in inheritance. Because in Islam, the biological children are legitimate children included in the kahf furud means the beneficiary group would certainly get a part, and has recorded it's obvious how much percentage of the part that she would get, but for the adopted child in Islam he does not get nothing at all because it is not included in any class, except he got a will of the heir or successor of the grants. In Islamic law has set out clearly the conditions of all the rights that will be earned by the biological children in inheritance while the adopted child still will not get any of the legacy of the heir. But the interesting thing in the "Mbaham" tribal customary law system is, let even children have been clearly the legitimate heir in the family and Muslim may not necessarily be able to instantly get his share in the inheritance, because children included in the older tradition.

\section{Clossing}

\subsection{Conclusion}

- The comparison of the rights of the biological children and adopted-children in the inheritance according to "Mbaham" tribe customary law and Islamic law is located from the portion of each child, along with its position in the family. Good-and-Bad is clearly visible when viewed from the perspective of Islamic law, which in the inheritance adopted-children do not have any rights to get the inheritance but he's entitled to probate if there is and is given by the heir. In contrast to the biological children of good-and- bad in inheritance is very uncertain because of the rights of children in inheritance is fixed and percentage of the part that has been determined, with the Qur'an as a reference benchmark and guidelines. The biological children also have the legal right in the inheritance according to Islam because he is included in the Kahf furud, that is people who have determined his share in inheritance. However, according to the customs of the tribe of "Mbaham" children may be in accordance with the provisions of Islam but if any adopted child, foster child who has entered the customary admit and the right it could be the same with the children, even children can be excluded with some reason according to the provisions and rules of custom.

- Then the role of the notary in the agreement of inheritance that is; it can create the certificate at the request of the heirs to be used for the heir in the bank property of the disbursement, but affidavits beneficiary can also be made under the authority of the upper hand heirs, and no doubt if that happens the bank requested that the SKW in giving the sign or approvement, this is where the role of the notary agreement made an affirmation the beneficiary based on affidavits heirs which are made under the hand 
of the agreement, and from the agreement the parties of the Bank will disburse the funds belonged to the heir to the heir.

- The equality of adopted-children and biological children in inheritance according to Islamic law is located on the right get heritage, but with a different way of getting the legacy fixed to the adopted child, the main benchmark in the Islamic heritage is the biological children, because he was the highlight. But in the customary law of the tribe of "Mbaham" adopted children and biological children are considered equal rights of inheritance because it is considered the same as the son of customs that deserve a legacy of family.

- The difference between the rights of biological children and adopted children in the inheritance according to Islamic law is very apparent from the provisions of the rules of Islamic jurisprudence that are bound to the quran, which is where the biological children have their place and get the legacy of the heir apparent, but for a foster children, they absolutely didn't get any because there were no blood relations and considered not included in the get inheritance. The opposite of Islamic law, tribal customary law system "Mbaham" in fact upholding the adopted child if the adopted child the upholding of customary rules anyway.

\subsection{Suggestion}

- The author suggests, to compare the rights of adopted children and biological children in Indigenous heritage as well as Islamic law or religion, inagreement we need to review the earlier rules which were accepted by the community in order not to conflict within the family, especially if in indigenous peoples law embraced a religion that made the reference and the guidelines in determining the rights of the beneficiary. A public notary who provided services in the making of affidavits heir or beneficiary upon the affirmation of authority certificate of heirs are made under the hands,

- The equality of adopted children and biological children in inheritance according to Islamic law has been set, although the adopted child can get the inheritance in different ways, namely with the heirs give the probate or grant to a foster child, writer recommend that if in a family there are indigenous peoples embraced Islam should nonetheless use the sharee'ah of Islam because Islamic law is the law of remains that could not be personalized way.

- The differences are so striking against adopted children and biological children that may actually be simplified with when in the family traditions embraced the teachings of the Islamic religion, can choose which is more appropriate to determine the rights of each person in the family, may not necessarily be directly using the customary rules which can be fickle in the deliberation of the indigenous.

\section{References}

[1] Sudarsono 2007 Kamus Hukum Cet VRineka Cipta Jakarta

[2] C.S.T Kansil and Christine 2011 Pengantar Hukum Indonesia Rineka Cipta Jakarta

[3] Soegianto 2015 Etika Profesi dan Perlindungan Hukum bagi Notaris CV Farisma Indonesia Yogyakarta

[4] Mulyoto 2012 Perjanjian edisi revisi Cakrawala Media Yogyajakarta

[5] Soerjono Soekamto 1987 Pengantar Penelitian Hukum Universitas Indonesia Press Jakarta

[6] http://belajarpsikologi.com accessed on $21^{\text {st }}$ April 2018 